\title{
Fungi and Bacteria in Indoor Cultural Heritage Environments: Microbial-related Risks for Artworks and Human Health
}

\author{
Enza Di Carlo ${ }^{1}$, Rosa Chisesi ${ }^{1}$, Giovanna Barresi ${ }^{1}$, Salvatore Barbaro ${ }^{2}$, Giovanna Lombardo ${ }^{1}$, \\ Valentina Rotolo ${ }^{1}$, Mauro Sebastianelli ${ }^{3}$, Giovanni Travagliato ${ }^{4}$, Franco Palla," \\ ${ }^{1}$ Laboratory of Biology and Biotechnology for Cultural Heritage, Department STEBICEF, University of Palermo, Italy \\ ${ }^{2}$ Interdepartmental Centre CIRIAS, University of Palermo, Italy \\ ${ }^{3}$ Diocesan Museum of Palermo, Italy \\ ${ }^{4}$ Diocesan Historical Archive of Palermo, Italy
}

Copyright $\mathrm{O} 2016$ by authors, all rights reserved. Authors agree that this article remains permanently open access under the terms of the Creative Commons Attribution License 4.0 International License

\begin{abstract}
Cultural heritage constitutive materials can provide excellent substrates for microbial colonization, highly influenced by thermo-hygrometric parameters. In cultural heritage-related environments, a detrimental microbial load may be present both on manufacts surface and in the aerosol. In this study, bacterial and fungal colonisation has been investigated in three Sicilian confined environments (archive, cave and hypogea), each with peculiar structures and different thermo-hygrometric parameters. Particular attention has been paid to microorganisms able to induce artifacts biodeterioration and to release biological particles in the aerosol (spores, cellular debrides, toxins and allergens) potentially dangerous for the human health (visitors/users). Results provided information on the composition of the biological consortia, highlighting also the symbiotic relationships between micro (cyanobacteria, bacteria and fungi) and macro-organisms (plants, bryophyte and insects). The results of this integrated approach, including molecular biology techniques, are essential for a complete understanding of both microbial colonization of the cultural objects and the potential relationship with illness to human.
\end{abstract}

Keywords Aerobiology, Bioaerosol, Biodeterioration, Healthcare, Preventive Conservation

\section{Introduction}

The indoor air can be considered a dynamic system, in which particles of vary origin are transported, transferred, and displaced from one environment on the other $[1,2]$.

It is well-known that bacterial cells and cellular fragments, fungal spores and related metabolic products are dispersed in the airborne influencing humans and cultural heritage [3-5]. Moreover, the pollutants (e.g. sulfur and nitrogen oxides, ozone, particulates) transported by air flow can accelerate the deterioration of cultural assets, also influencing the metabolic activity of microbial colonisers [4]. Generally, indoor air contains a complex mixture of microorganisms (fungi, bacteria, viruses) and related organic compounds (endotoxins, metabolites, toxins, microbial fragments), along with non-biological particles (dust, organic and inorganic gases). The bioaresol contributes from 5 to $34 \%$ of total indoor air pollutants, are different in size $(20 \mathrm{~nm}$ to $>100 \mu \mathrm{m})$ and composition $[2$, 5].

Cultural heritage environments (libraries, archives, museums, storage depositories, hypogea, etc.) are frequently in old or monumental buildings (including cellars, basements, and attics) and only a small number can be considered specifically designed for housing cultural heritage. In these environments, an inappropriate ventilating or air-conditioning systems may cause fluctuations of temperature and relative humidity. If the microclimate parameters are not stable, biological particles can evolve in a potential threat to objects and humans [6-11]. The exposure to some microorganisms, in particular Staphylococcus sp., thermophiles actinomycetes or mycetes, such as Aspergillus, Alternaria, Penicillium, Aureobasidium may induce illness as rhinitis, sinusitis, asthma or alveolitis in humans. Such microorganisms are the most commonly genera isolated from libraries/archives and museums environments [12]. In particular, the exposure to fungal bioaerosol, consisting of spores, hyphal fragments and volatile fungal metabolites (VFMs), may result in serious respiratory infections in immunocompromised individuals and can cause bronchial irritation and allergy (allergic asthma, allergic rhinitis, allergic sinusitis, broncho pulmonary mycoses, and hypersensitivity pneumonitis) 
[13].

Therefore, for an appropriate management of all the potential risks due to bio-pollutants in indoor environments, must be considered: $i$ ) the type of location, building and geographical collocation of the cultural heritage-related environment; ii) that people (visitors/users) represent for indoor environments a relevant source of microbial air contamination (through the skin, the hair or when people cough, snooze, talk); iii) how stable are the microclimate parameters such relative humidity $(\mathrm{RH})$, temperature, including lighting and airflow [14-17].

The monitoring of microbial contamination both on works of art surface and in the surrounding air represents the basis for a proper conservation strategy, in order to gather information to identify specific hazard that should thus lead to a prompt intervention providing a proper conservative action.

In this study, as effort for the standardization of monitoring protocols, the microbial colonisation of both manufacts and environmental bioaerosol was analysed through an interdisciplinary approach in three different cultural sites in Sicily (Italy). So far, several researches have proved that molecular biology is extremely useful also in the field of conservation of cultural assets [18-21]. Interest in assessing microbial air contamination has particularly increased over the last years, in relation to the potentially harmful effects related to microbial systems that can be amplified by the presence of many other compounds [22-27]. In this study, the microbial consortia were revealed and identified in three different Sicilian confined environments, with peculiar structural features, microclimates and uses: the Diocesan Historic Archive, Palermo (documentary funds) [28], the Sibilla Antrum, Marsala (frescoes) [29] and the Saints Cave, Licodia Eubea (mural paintings) [30]. The microorganisms colonising the aerosol were sampled by active method and identified by an integrated approach using Optical and Confocal Laser Scanning Microscopy (OM, CLSM), in vitro culture, amplification of genomic DNA target sequences (PCR), sequencing, and sequence analyses [31-33]. The results of this investigation were useful to implement sampling and diagnosis procedures, allowing a rapid identification of microbial taxa, also in complex consortia. Considering that the system human /artefact/ environment is a dynamic system, the characterization and potential correlation between surface and aerosol microorganisms allows to perform an adequate preventive strategies in order to reduce the potential negative effects on both works of art and human health.

\section{Materials and Methods}

\subsection{Environments}

Three different cultural heritage environments (Figure 1) have been selected to reveal microbial colonization (bacteria, fungi, cyanobacteria) both in aerosol and on artifacts stored/exposed inside.

Diocesan Historic Archive (Figure 1, blue dot). Ancient building in the city center of Palermo (urban environment), converted since 1945 in Archive. The archive is characterized by reduced indoor-outdoor air exchange, stable thermo-hygrometric parameters and a limited fruition of users.

Sibilla Antrum (Figure 1, red dot). A hypogeal environment (400 B.C.), closed to the sea cost of Marsala (Trapani), where airborne particulate was mainly introduced and moved by visitors. The thermo-hygrometric parameters of the environment were quite stable: high $\mathrm{RH}(75-90 \%)$ and low temperature $\left(15-19^{\circ} \mathrm{C}\right)$.

The Saints Cave (Figure 1, orange dot). A cave confined environment (XII-XIV sec.) in Licodia Eubea (Catania) landscape where a spread biological colonization was revealed. The cave environment is strongly influenced by surrounding countryside, day-night cycles and seasonal variations in temperature and $\mathrm{RH}$ values $\left(15-30^{\circ} \mathrm{C}\right.$; $29-73 \%)$.

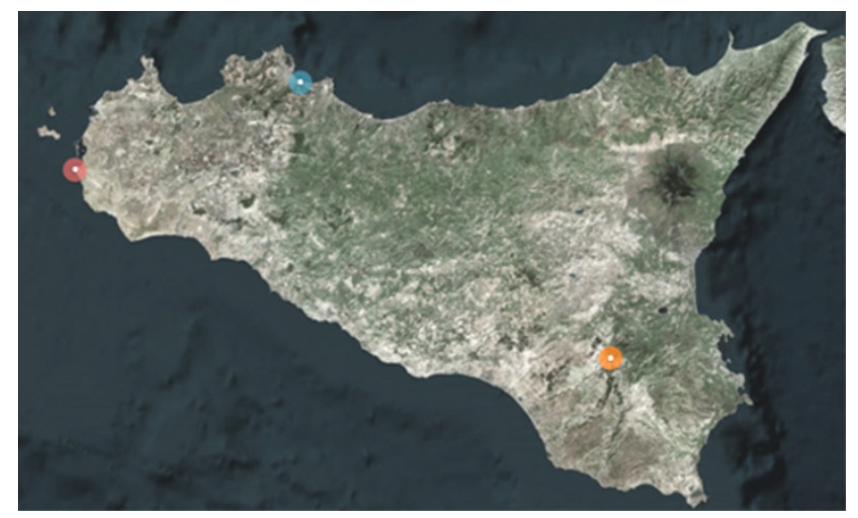

(Image from Bing Maps, http://www.bing.com/mapspreview?cc=it)

Figure 1. The three sampling cultural environments located in Sicily (Italy). The Saints Cave, Alia (orange dot); Sibilla Antrum, Marsala (red dot); Diocesan Historic Archive, Palermo (blue dot).

\subsection{Sampling Strategies}

\subsubsection{Aerosols}

In all environments, active sampling (in twice) was performed in order to detect fungal and bacterial cells and spores.

For active sampling a portable AirPort MD8 sampler (Sartorius) with a flow rate of $100 \mathrm{~L} / \mathrm{min}$, equipped with sterile disposable gelatin filter was used; this filter maintains the viability of the collected microorganisms and it is completely water-soluble [32]. After sampling, one filter was utilized for in vitro culture, laying it onto solid culture media. The second filter was dissolved in 1X TE solution (10 mM TRIS-HCL pH7.5/1 mM EDTA) and utilized for the direct extraction of microbial genomic DNA for molecular biology investigations. 


\subsubsection{Artwork surfaces}

The artworks analysed:

a) Diocesan Historic Archive (DHA), paper documentary funds;

b) Sibilla Antrum (SA), frescoes;

c) Saint Cave (SC), mural painting.

As showed in Table 1, in relationship to manufacts constitutive materials and biological colonization, samplings were carried out following different criteria: $i$ ) micro-fragments of biofilm from frescoes/mural painting surface were collected by sterile scalpel; $i$ i) sterile swabs or

$\mathrm{H}^{+}$Nylon Amersham-membrane fragments. Membranes fragments $(2 \times 4 \mathrm{~cm})$ were put in contact with investigated surfaces pressing for 30 seconds.

Table 1. Samplings in the investigated environments.

\begin{tabular}{|c|c|c|c|}
\hline Environments & DHA & SA & SC \\
\hline Artworks & $\begin{array}{c}\text { documentary } \\
\text { found }\end{array}$ & Frescoes & $\begin{array}{c}\text { Mural } \\
\text { painting }\end{array}$ \\
\hline $\begin{array}{c}\text { Surface sampling } \\
\text { tools }\end{array}$ & $\begin{array}{c}\text { swab } \\
\text { membrane }\end{array}$ & scalpel & $\begin{array}{c}\text { scalpel } \\
\text { membrane }\end{array}$ \\
\hline
\end{tabular}

In vitro culture

Sabouraud and Nutrient Agar (Difco) plates seeded by sterile swab, Nylon membrane fragment or Gelatin filter have been incubated at $30^{\circ} \mathrm{C}$ for $5-7$ days (fungi) or 16-48 hours (bacteria) [33-35].

\subsection{Microscopy Analysis}

The morphology of both bacteria and fungi isolated colonies was observed by stereomicroscope (Wild-M1B, 14X). In particular, conidiophores and conidia fungal structures were examined, after Lugol's iodine staining, by Optical Microscope (Leica, 40X ).

Biofilm micro-fragments from Saint Cave were analysed by CLSM (Olympus FV 300 - Argon, 488.0nm, He-Ne, $543.5 \mathrm{~nm}$ ), exploiting their self-fluorescence property [36].

\subsection{Molecular Investigation}

Microbial genomic DNA was extracted from: $i$ ) aerosol biological particles collected by gelatin filters; $i$ ) surfaces biological particles collected by Nylon membrane fragments; iii) fungi and bacteria colonies isolated on Sabouraud and Nutrient Agar. To extract microbial genomic DNA, the GeneJET Genomic DNA Purification kit (Fermentas) protocol was properly modify in relation to the samples characteristics (for fungi colonies or biofilm, the incubation was extended up to 12 hours at $60^{\circ} \mathrm{C}$ ).

\subsubsection{Polymerase Chain Reaction (PCR)}

Genomic DNA molecules were utilized as template for in vitro amplification (PCR) of target sequences (bacterial 16S-rDNA gene or Internal Transcribed Sequence - rDNA, specific for bacteria or fungi). Each PCR reaction mixture consisted of:

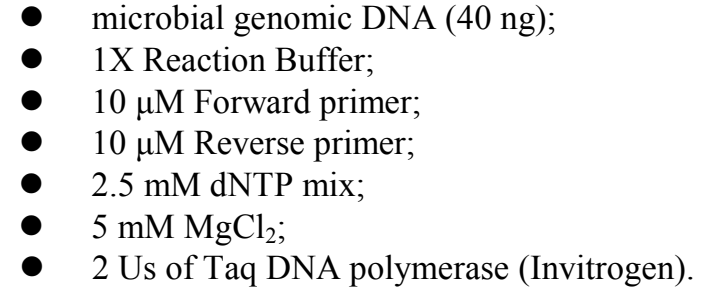

The PCR amplification profiles were: 1 cycle of denaturation at $95^{\circ} \mathrm{C}$ for $5 \mathrm{~min}$, followed by 30 cycles of: denaturation at $94^{\circ} \mathrm{C}$ for $1 \mathrm{~min}$, annealing at $52^{\circ} \mathrm{C}$ up to $58^{\circ} \mathrm{C}$ for $1 \mathrm{~min}$, extension at $72^{\circ} \mathrm{C}$ for $2 \mathrm{~min}$. A final extension step $\left(72^{\circ} \mathrm{C}\right.$ for $5 \mathrm{~min}$ ) was added to ensure that all PCR products were full-length.

Primers:

1) Cyanobacteria $16 \mathrm{~S}$ rDNA primers: $\mathrm{Cy} 27 \mathrm{~F} 1$ and Cy408R (annealing, $55^{\circ} \mathrm{C}$ ) [37], or new primers CYAN-ROB-F and CYAN-ROB-R (annealing, $\left.58^{\circ} \mathrm{C}\right)$.

2) Bacteria ITS-rDNA primers: ITS F and ITS R (annealing, $52^{\circ} \mathrm{C}$ ) [38].

3) Fungi ITS-rDNA primers: ITS1-Fs: 5'CTTGGTCATTTAGAGGAAGTAA- 3' and ITS4 (annealing, $55^{\circ} \mathrm{C}$ ) [38].

PCR products were resolved by electrophoresis on $2 \%$ Agarose gel. Nucleotide composition was determined by MWG Operon Sequencing Service, sequences comparison was performed by BLAST platform [37-39].

\subsection{Microclimate parameters}

Thermo-hygrometric parameters (temperature and relative humidity) were measured, in the all environments, by portable Rotronic HygroPalm (HP22) and by HOBO U-12 006 Data Logger. Monitoring was performed following the Italian Standard UNI 10829 [40] and during one year.

Table 2. Environmental thermo-hygrometric parameters.

\begin{tabular}{|c|c|c|c|}
\hline Environments & DHA & SC & SA \\
\hline $\begin{array}{c}\text { Relative Humidity } \\
\text { (\%) }\end{array}$ & $60-65$ & $29-73$ & $75-90$ \\
\hline Temperature $\left({ }^{\circ} \mathbf{C}\right)$ & $18-22$ & $15-30$ & $15-19$ \\
\hline
\end{tabular}

\section{Results and Discussion}

\subsection{Identification of Microbial Taxa}

\subsubsection{Aerosols}

Culturable and non-culturable microorganisms were identified combining in vitro culture, microscopy analysis and molecular investigations (qualitative data).

Quantitative microbial concentrations was only estimated referring to culturable fungi and bacteria colonies as Colony Forming Units /air volume $\left(\mathrm{CFU} / \mathrm{m}^{3}\right)$. 
Investigation results point out the presence of Penicillium spp. and Aspergillus spp. (Figure 2), besides Alternaria spp. (Figure 3) in both Diocesan Historic Archive and Saint Cave environments.

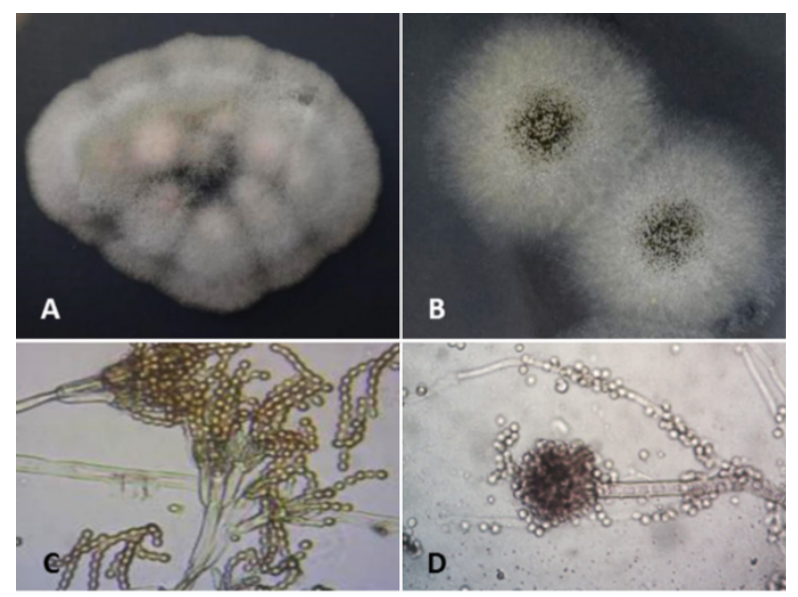

Figure 2. Penicillum spp. (A) and Aspergillus spp. (B) colonies on Sabouraud media. Corresponding conidiophores structures (C-D) after Lugol's staining.

Combining in vitro culture (Sabouraud agar) and optical microscopy analysis, fungi belonging to Cladosporium genera were revealed in Sibilla Antrum environment (Figure 4). Molecular investigation performed by in vitro amplification of 18-26S rDNA target sequences pointed out the presence of Penicillium spp. (Figure 5, lane 4) and Penicillium chrysogenum (Figure 5, lane 5), also confirming Cladosporium spp. (Figure 5, lanes 6-8).

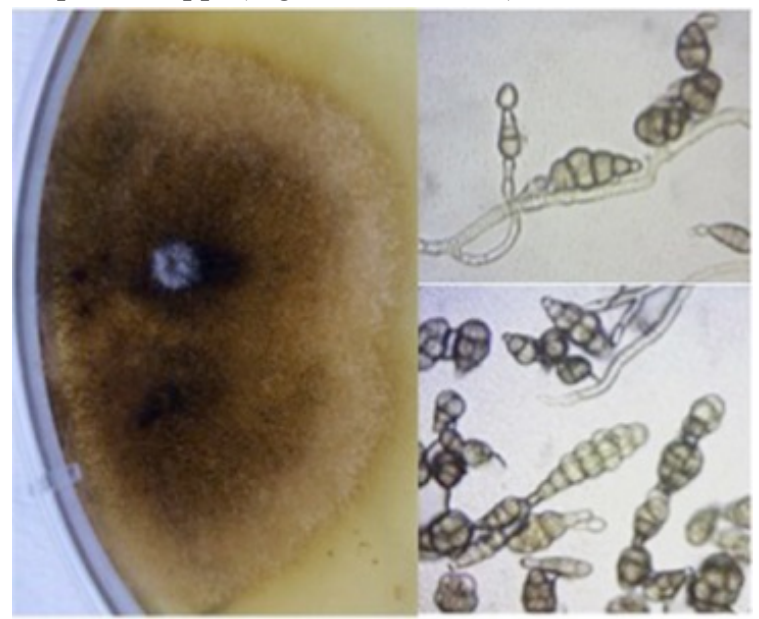

Figure 3. Colonies of Alternaria spp. grown on Sabouraud media (left) and the corresponding fungal structures after Lugol's staining (right).
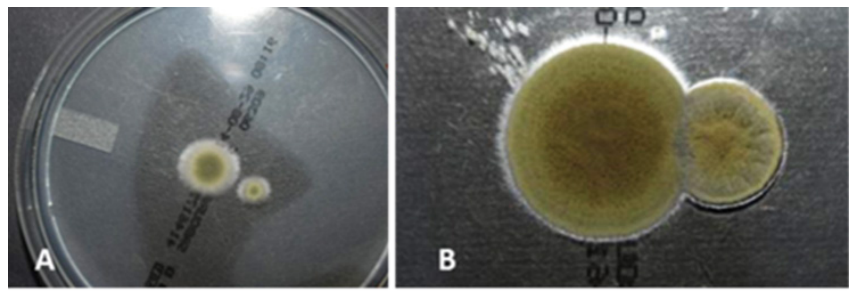

Figure 4. Cladosporium spp. colonies grown, after 5 days (A), 7 days (B) at $30^{\circ} \mathrm{C}$, on Sabouraud agar inoculated by Gelatin filter fragment utilized for aerosol sampling in Sibilla Antrum; fragment dissolved after few minutes (it is still visible the corresponding triangular shape, A).

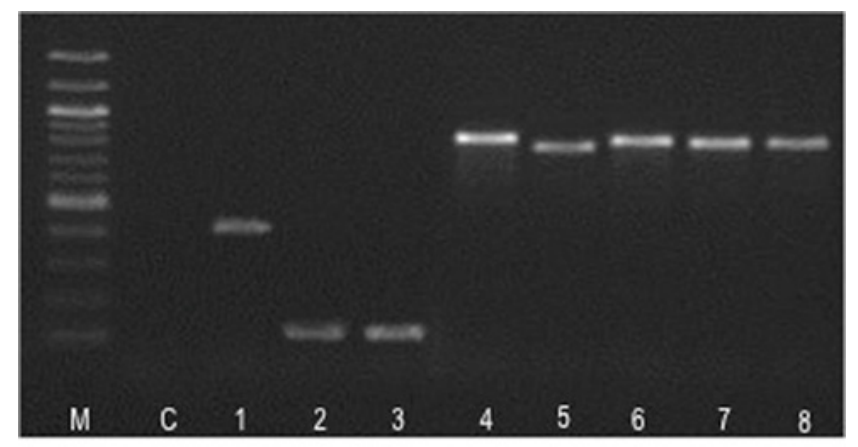

Figure 5. PCR products resolved by gel electrophoresis on $2 \%$ Agarose gel. Saint Cave: 16S rDNA- PCR products: 1) Cyanobium spp. (420 bp); 2-3) Chroococcus spp. (110 bp). 18-26S rDNA (ITS)-PCR-products: 4) Penicillum spp. (850 bp); 5) Cladosporium spp. (800 bp); 6- 8) Penicillium chrysogenum (850 bp). Marker Sharp Mass (M), negative control (C).

Considering the potential adverse health effects, particular attention must be payed to Aspergillus, Alternaria and Penicillium. These mycetes genera are ubiquitous and present in air, surfaces, soil and plants, and are able to produce toxins and asexual spores that may constitute human allergens. Some Aspergillus species are pathogenic to humans and animals and are responsible for clinical manifestations. Particularly, A. niger is one of the most common species associated with respiratory tract infections. Inhalation of Alternaria spores can cause allergies and as reported for A. alternata the exposure represents a risk factor for asthma. The genus Penicillium may cause various events associated with Sick Building Syndrome (SBS), such as irritation of the eyes and respiratory tract, headache, drowsiness, skin rash and itching of the skin [41-43].

Although less frequent than fungal, bacterial species isolated from both the surface of artefacts and the aerosol in cultural heritage environments are enough numerous showing different pigmentation and metabolic activity producing a complex secondary metabolisms pathways [44]. Moreover, spore-forming bacteria able to produce toxins such as Bacillus spp., $B$. thuringiensis, $B$. weihenstephanensis were identified in the Saints Cave environment.

\subsubsection{Artwork Surfaces}

Surfaces microbial contamination is closely linked to the presence and concentration of microorganisms in the aerosol, then microbial species can be found on artworks surfaces [45]. This was true in Diocesan Historic Archive where fungal colonisation by Aspergillus spp., Alternaria spp. and Penicilium spp., revealed in the aerosol was confirmed on paper documents by DNA-based investigation [20]. These documents were also colonised by Bacillus simplex, Bacillus flexus, Micrococcus spp., Micrococcus luteus, Arthrobacter spp. (Table 3).

On Saints Cave fresco, Penicillium chrysogenum (F1) and Aspergillus niger (F2) were revealed by microscopy observations of both colonies (Figure $6 \mathrm{a}, \mathrm{c}$ ) and conidia or conidiophore structures morphologies (Figure $6 \mathrm{~b}$, d). Moreover, DNA-based investigation allowed the identification of Chaetomium spp. and Scopulariopsis spp. 


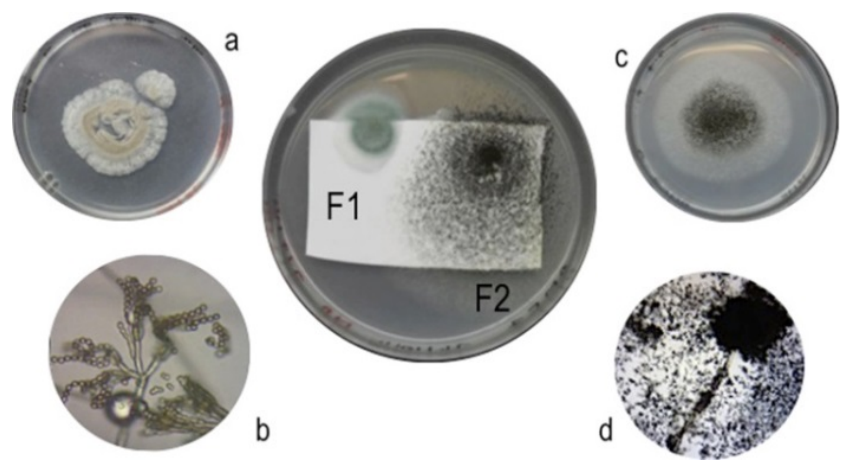

Figure 6. Saints Cave fresco. Isolated Penicillium chrysogenum (F1), sub-culture (a) and Aspergillum niger (F2), sub-culture (c) colonies grew on Nylon $\mathrm{H}^{+}$fragments lying on Sabouraud agar medium. The corresponding fungi structures were observed by optical microscopy $(40 \mathrm{X})$ after Lugol's staining (b, d).

These Ascomycetes, normally found in the soil and plant debris, are contaminants of mouldy dump buildings that can be associated with human diseases, such as keratitis, mycosis, pulmonary infections.

Spore-forming bacteria were revealed in frescoes surface of Sibilla Antrum (Bacillus spp.) and Saints Cave (Bacillus spp., Terribacillus spp.) frescoes (Table 3 ) by using in vitro culture and molecular investigations.

\section{Biofilms}

Particularly in Saint Cave, a pigmented biofilm was revealed in several fresco area. The microbial composition of biofilm fragments were investigated by both CLSM (Olympus FV 300) analysis and molecular investigation. A plentiful colonization by cyanobacteria, showed in Figure 7, was revealed and confirmed by molecular investigation. PCR products and related sequences analysis identified Cyanobium spp. (Figure 5- lane 1) and Chroococcus spp. (Figure 5- lanes 2 and 3).

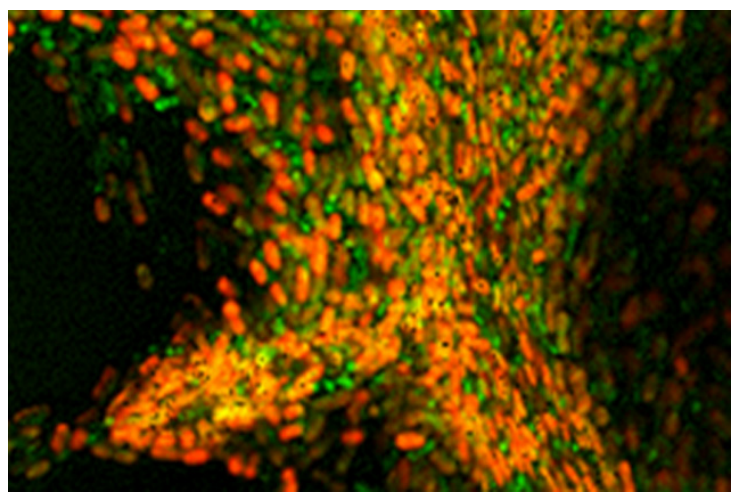

Figure 7. Biofilm imaging by Confocal Laser Scanning showing cyanobacteria and microalgae.

Table 3. Fungi and bacteria in Diocesan Historic Archive (DHA), Sibilla Antrum (SA) and the Saints Cave (SC); bioaerosol (æx) or artworks surfaces ( $\otimes$ ).

\begin{tabular}{|c|c|c|c|c|}
\hline & & $D H A$ & $S C$ & $S A$ \\
\hline Fungi & $\begin{array}{l}\text { Aspergillus spp. } \\
\text { A. niger } \\
\text { Alternaria spp. } \\
\text { Cladosporium spp. } \\
\text { Penicillium spp. } \\
\text { P. chrysogenum } \\
\text { Scopulariopsis spp. } \\
\text { Chaetonium spp. }\end{array}$ & $\begin{array}{l}x \otimes \\
x \otimes \\
x \otimes\end{array}$ & $\begin{array}{l}\otimes x \\
\otimes \\
\not x \\
\otimes \\
\otimes \\
\otimes \\
\otimes\end{array}$ & $\begin{array}{l}x x \\
\not x \\
x x\end{array}$ \\
\hline Bacteria & $\begin{array}{l}\text { Arthrobacter spp. } \\
\text { Bacillus spp. } \\
\text { B. flexus } \\
\text { B. simplex } \\
\text { B. thuringiensis } \\
\text { B. weihenstephanensis } \\
\text { Micrococcus spp. } \\
\text { M. luteus } \\
\text { Terribacillus spp. }\end{array}$ & $\begin{array}{l}\otimes \\
\otimes \\
\otimes \\
\otimes \\
\otimes \\
\otimes \\
\otimes\end{array}$ & $\begin{array}{l}x x \otimes \\
x x \\
x x\end{array}$ & $\otimes$ \\
\hline
\end{tabular}




\section{Conclusions}

In this work, we emphasize the use of multiple approaches to outline the microbial contamination in indoor environment of three Sicilian cultural sites and its role in both artifacts deterioration and potential effects on visitors/operators health. In order to detect and characterize the microbial contamination, surface (swab, nylon membranes) and aerosol samplings (active) were performed.

In each environment, specific microclimatic conditions exist and, in accordance with appropriate conservation protocols, they must be constantly monitored.

Microbiological monitoring in order to identify specific risks for artefacts and operators/visitors must be also performed. The collected information should thus lead to timely intervention by implementing the appropriate remedial action, setting reliable risk models for exposure to microbial systems, in order to adequately address both routine circumstances.

The spreading of stable and synergistic consortia of microorganisms induced important transformations over the artistic surfaces, led by the trigger of metabolic processes.

Particularly for Saint Cave environment, the nature of the lithic substrates, characterized by soft, crumbly and porous rocks, such as limestone or sandstone, as well as the continuous indoor/outdoor air exchanges with the countryside, enhances the growth of several microbial strains.

Instead, the few number of microbial taxa isolated from Sibilla Antrum environment it is probably due to the stable environmental parameters and the reduced number of visitors.

Finally, the bacterial and fungal taxa isolated in Diocesan Historic Archive are strictly associated to the documentary found constitutive materials (paper, parchment), the occurrence of users and to an inefficient air ventilation.

The results of this study, besides performing a suitable conservation strategy, may contribute toward the definition of standardized methods for assessing the biological and climate quality of indoor heritage environments, as suggested by Pasquarella et al. [35]. It is therefore essential to identify airborne biological particles to determine their potential role in triggering the degradation of cultural heritage and in the effects on the operators and visitors health, considering that the system human/artefact/environment is a dynamic system.

\section{Acknowledgements}

We would like to thank the Archeoclub of Licodia Eubea, the Soprintendenza ai Beni Culturali di Catania and the Municipio di Licodia Eubea, the Soprintendenza ai Beni Culturali di Trapani and the Archivio Diocesano di Palermo.

This study was developed in the research project It@cha - Italian Technologies for Advanced application in Cultural
Heritage, under grant PON 01_00625 "Ricerca e Competitività" 2007-2013. Special acknowledgements to G. Morici for CLSM and C. Di Liberto for SEM analysis.

\section{REFERENCES}

[1] S. Lanjewar, K. Sharma. Intramural Aeromycoflora of Rice Mill of Chhattisgarh, International Science Journal, Vol.1, No 1, 40-45, 2014.

[2] J. Mandal, H. Brandl. Bioaerosols in Indoor Environment - A Review with Special Reference to Residential and Occupational Locations, The Open environmental and Biological monitoring Journal, Vol.4, 83-96, 2011.

[3] A. Nevalainen, M. Täubel, A. Hyvärinen. Health effects of fungi, bacteria and other bioparticles. In: Synergic Influence of Gaseous, Particulate, and Biological Pollutants on Human Health. Edited by J.S. Pastuszka. Taylor \& Francis Group, 176-184, 2015.

[4] G. Caneva, M.P. Nugari, O. Salvadori. Plant Biology for Cultural Heritage. Biodeterioration and Conservation. The Getty Conservation Institute, Los Angeles, CA, 2008.

[5] P. Srikanth, S. Sudharsanam, R. Steinberg. Bio-aerosols in indoor environment: composition, health effects and analysis, Indian Journal of Medical Microbiology, Vol. 26, No. 4, 302-312, 2008.

[6] M. Lazardis, E. Katsivela, I. Kopanakis, Raisi L., G. Panagiaris,. Indoor/outdoor particulate matter concentrations and microbial load in cultural heritage collections, heritage Science, Vol. 3, No. 34, 2015.

[7] F. Gallo, G. Pasquariello, P. Valenti. Libraries and Archives. In: Cultural Heritage and Aerobiology, Methods and Measurement Techniques for Biodeterioration Monitoring. Edited by P. Mandrioli, G. Caneva, C. Sabbioni, Kluwer Academic Publishers Boston/London, , 175-193, 2003.

[8] P. Mandrioli, G. Caneva, C. Sabbioni. Cultural heritage and aerobiology. Methods and measurement techniques for biodeterioration monitoring. Kluwer Academic Publishers Dordrecht, 2003.

[9] L. Hoffmann. Caves and other low-light environments: aerophytic photoautotrophic microorganisms. In Encyclopedia of Environmental Microbiology. Edited by Bitton G. New York, NY., John Wiley \& Sons, 171-177, 2002.

[10] G. Pasquariello, M.C. Sclocchi, D. Matè, P. Valenti. Prevention of Biodeterioration. In : Plant Biology for Cultural Heritage: Biodeterioration and Conservation. Edited by G. Caneva, P. Nugari, O. Salvadori, Getty Conservation Institute, Vol. 1, 273- 286, 2008.

[11] J. Grau-Bové, M. Strlic`. Fine particulate matter in indoor cultural heritage: a literature review, Heritage Science, Vol.1, No. 8, 2013.

[12] N. Mesquita, N.M.A. Portugal, S. Videira, S.R. Eccheverria, A.M.L. Bandeira. Fungal diversity in ancient documents. A case study on the Archive of the University of Coimbra, Int Biodet \& Biodegr, Vol. 63, 626-629, 2009. 
[13] A.A. Haleem Khan, S. Mohan Karuppayil. Fungal pollution of indoor environments and its management, Saudi Journal of Biological Science, Vol. 19, No. 4, 405-426, 2012.

[14] E. Garcia-Anton, A. Fernandez-Cortes, M. Alvarez-Gallego, S. Sanchez-Moral, S. Cuezva, E. Sanz-Rubio, V. Jurado, E. Porca, C. Saiz-Jimenez. Entry and dispersion of microorganisms inside Altamira Cave: new evidences from aerobiological and atmospheric gases survey. In: Science and Technology for the Conservation of Cultural Heritage. Edited By M.A. Rogeiro-Candelera, M. Lazzari, E. Cano, CRC Press, London, 55-58, 2013.

[15] W.C. Noble, D.A. Somerville. Microbiology of the human skin, Lloyd-Luke, London, 1981.

[16] E.C. Cole, C.E. Cook. Characterization of infectious aerosol in health care facilities: An aid to effective engineering controls and preventive strategies, American Journal of Infection Control, Vol. 26, No. 4, 453-464, 1998.

[17] G. Caneva, F. Gallo, O. Maggi, P. Valenti. Influence of physical parameters on the development of organisms that promote biodeterioration. In: Cultural Heritage and Aerobiology, Methods and Measurement Techniques for Biodeterioration Monitoring. Edited by Mandrioli P, Caneva G, Sabbioni C, Kluwer Academic Publishers Boston/London, 73-79, 2003.

[18] J.M. Gonzales. Overview on existing molecular techniques with potential interest in cultural heritage. In: Molecular Biology and Cultural Heritage. Edited by C. Saiz-Jimenez, Balkema Publishers, 3-13, 2003.

[19] K. Sterflinger, G. Piñar. Microbial deterioration of cultural heritage and works of art - tilting at windmills?, Appl. Microbiol. Biotechnol., Vol. 97, No. 22, 9637-9646, 2013.

[20] F. Palla, F.P. Mancuso,N. Billeci. Multiple approaches to identify bacteria in archaeological waterlogged wood. Journal of Cultural Heritage, Vol. 14, No. 3, e61-e64, 2013.

[21] G. Barresi, E. Di Carlo, M.R. Trapani, M.G. Parisi, C. Chillè, M.F. Mulè, M. Cammarata, F. Palla. Marine organisms as source of bioactive molecules applied in restoration projects, Heritage Science, Vol. 3, No.17, 2015.

[22] F. Palla. Biological risks for the conservation and exhibition of historical-artistic artefacts in confined spaces. In: Risk management in the field of cultural heritage: museums, libraries, archives. Edited by Lorusso S, Natali A, Matteucci C, Palla F, MIMESIS Edizioni, 95-108, 2015.

[23] J. Peltola, M. A. Andersson, T. Haahtela, H. Mussalo-Rauhamaa, F. A. Rainey, M. Kroppenstedt, R. A. Samson, M. S. Salkinoja-Salonen. Toxic-metaboliteproducing bacteria and fungus in an indoor environment, Applied Environmental Microbiology, Vol. 67, No. 7, 3269-3274, 2001.

[24] M.S. Salkinoja-Salonen, J. Peltola, M.A. Andersson, C. Saiz-Jimenez. Microbial toxins in moisture damaged indoor environment and cultural assets. In: Molecular Biology and Cultural Heritag. Edited by Saiz-Jimenez C, Balkema Publishers, 93-105, 2003.

[25] B.S. Levy, D.H. Wegman, S.L. Baron, R.K. Sokas. Occupational and Environmental Health: Recognizing and Preventing Disease. 6th Edition, Oxford University Press, 2011.
[26] M.D.V. Ward, Y.J. Chung, L.B. Copeland, D.L. Doerfler. A comparison of the allergic responses induced by Penicillium chrysogenum and house dust mite extracts in a mouse model, Indoor air, Vol. 20, No. 5, 380-391, 2010.

[27] R.E. Esch, C.J. Hartsell, R. Crenshaw, R.S. Jacobson. Common Allergenic Pollens, Fungi, Animals, and Arthropods, Clinical Reviews in Allergy and Immunology, Vol. 21, 261-292, 2001.

[28] G. Travagliato. Storia e Arte nella Scrittura. Ed. Centro Studi Aurora, 2000.

[29] M.R. Carra. Testimonianze paleocristiane. In: AA.VV. Testimonianze archeologiche dal IV sec. a.C. al V sec. D.C. Lilibeo, Palermo, 1984.

[30] E. Bonacini. Il borgo cristiano di Licodia Eubea, Ed. UNI Service, Trento, 2008.

[31] J.M. Gonzales, C. Saiz-Jimenez. Application of molecular nucleic acid-based techniques for the study of microbial communities in monuments and artworks, International Microbiology, Vol. 8, No. 3, 189-194, 2005.

[32] F. Palla. Analytical techniques. In: Science and Conservation for Museum Collections, Edited by B. Fabbri Nardini, Firenze, 459-470, 2012

[33] F. Palla, L. Anello, S. Marineo, G. Lombardo. Characterization of bacterial community in indoor environment. In: Heritage, Weathering and Conservation, Edited by R. Fort, M. Alvarez de Buergo, M. Gomez-Heras, C. Vazquez-Calvo, Taylor \& Francis Group, 361-365, 2006.

[34] G. Pasquariello, G. Crupi, S. Strippoli, O. Maggi, P. Colaizzi, C. Balocco, C. Pasquarella. Microbial environmental monitoring in museums: preventive conservation of graphic collections. Conservation Science in Cultural Heritage, Vol. 14, No. 1, 275-289, 2014

[35] C. Pasquarella, G. Pasquariello, C. Balocco, E. Saccani, E. Marmonti, F. Palla, M. Ugolotti, O. Maggi, R. Albertini. Biological and microclimatic diagnosis in cultural heritage conservation: interdisciplinary research at Palatina library in Parma, Science Total Environment, Vol. 536, 557-567, 2015.

[36] F. Villa, B. Pitts, E. Lauchnor, F. Cappitelli, P. Stewart. Development of a laboratory model of a phototroph-heterotroph mixed-species biofilm at the stone/air interface, Frontiers in Microbiology, Vol. 6, No. 1251, 1-14, 2015.

[37] C.A. Crispim, C.C. Gaylarde, P.M. Gaylarde, J. Copp, B.A. Neilan. Molecular biology for investigation of cyanobacterial population in historic buildings in Brazil. In Molecular Biology and Cultural Heritage. Edited by Saiz-Jimenez C, Balkema Publishers, 141-144, 2003.

[38] F. Palla, N. Billeci, F.P. Mancuso, L. Pellegrino, L.C. Lorusso. Microscopy and molecular biology techniques for the study of biocenosis diversity in semi-confined environments, Conservation Science in Cultural Heritage, Vol. 10, 185-194, 2010.

[39] S.F. Altschul, T.L. Madden, A.A. Schäffer, J. Zhang, Z. Zhang, W. Miller, D.J. Lipman. Gapped BLAST and PSI-BLAST: a new generation of protein database search programs, Nucleic Acids Research, Vol. 25, No. 17, 3389-3402, 1997.

[40] UNI, 1999, Beni di interesse storico artistico. Condizioni ambientali di conservazione. Misurazione ed analisi. Italian 
Standard UNI 10829.

[41] S.C. Wilson, D.C. Straus. The presence of fungi associated with sick building syndrome in North America zoological institutions, J. Zoo. Wild Med., Vol. 33, No. 4, 322-327, 2002.

[42] F. Pinzari. Microbial ecology in indoor environments. The ecological and applied aspects of microbial contamination in archives, libraries and conservation environments. In: Sick building syndrome in public buildings and workplace, Chapter 9. Edited by Abdul-Wahab Al-Sulaiman SA, Elsevier, Burlimgton, 2011.
[43] P. M. Salo, S. J. Arbes, M. Sever, R. Jaramillo, R. D. Cohn, S. J. London, D. C. Zeldin. Exposure to Alternaria alternata in US homes is associated with asthma symptoms. The Journal of Allergy and Clinical Immunology, Vol. 118, No. 4, 892-898, 2006

[44] P. Sanmartín, A. De Araujo, A. Vasanthakumar. Melding the old with the new: trends in methods used to identify, monitor, and control microorganism on cultural heritage materials. Microbial Ecology, Vol. 71, No. 4, 1-17, 2016.

[45] C. Saiz-Jimenez, J. Gonzalez. Aerobiology and Cultural Heritage: Some reflections and future challenges. Aerobiologia Vol. 23, 89-90, 2007. 